\title{
Samsun İlinde Arpa Üretim Potansiyeli
}

\author{
Abdulveli SİRAT ${ }^{1}$, İsmail SEZER ${ }^{2}$ \\ ${ }^{I}$ Gümüshane Üniversitesi Siran Mustafa Beyaz MYO, Şiran-Gümüşhane \\ ${ }^{2}$ O.M.Ü. Ziraat Fakültesi, Tarla Bitkileri Bölümü, Samsun
}

Geliş tarihi/Received 06.05.2014

Düzeltilerek geliş tarihi/Received in revised form 17.07.2014

Kabul tarihi/Accepted 18.07.2014

\begin{abstract}
$\ddot{O} z e t$
Glda ve yem sanayinin temel ham maddelerinden biri olan arpa, dünya ve ülkemiz tarımında önemli bir tahıl cinsidir. Dünyada beslenme sorunu her geçen gün hızla artmaktadır. Bu sorunun çözümü için birbirinden oldukça farkl görüşler ileri sürülmektedir. Üzerinde uzlaşılan en önemli çözüm noktası ise bitkisel ve hayvansal üretimin artırlmasıdır. Ülkemizde gıda ve hayvan yemi olarak tüketilen ve ekonomik açıdan en önemli ürünler arasında bulunan arpa, buğdaydan sonra ikinci sırada gelmektedir. Bu çalışma, Türkiye arpa üretiminde önemli bir yere sahip olan Samsun İlinin üretim potansiyelini ortaya koymak amacıyla hazırlanmıştır.
\end{abstract}

Anahtar kelimeler: Samsun, Arpa, Üretim Potansiyeli

\section{The Potential Of Barley Production In Samsun Province}

\begin{abstract}
Barley, one of the basic raw material of the food and feed industry, is an important cereal in the world and our country as well. Nutritional problem is a rapidly increasing issue day by day all around the world. Many different ideas are suggested to solve this global challenge. The most poular solution agreed on is to increase the crop and livestock production. Barley which is consumed as food and animal feed and accepted among the most important crops economically in our country, ranks second after wheat. This study conducted to the determination of the production potential of Samsun province that has a considerable contribution in the barley production of Turkey.
\end{abstract}

Keywords: Samsun, Barley, Production Potential

\section{Giriş}

Günümüzde arpa, dünyada ve ülkemizde hayvan beslemede yemlik olarak ve endüstride malt bira yapımında kullanılmak üzere başlica iki amaçla yetiştirilmekte ve bu doğrultuda sslah edilmektedir. Hayvan yemi olarak tüketilen tahıllar içerisinde ilk sıralarda yer alan arpa tanesi yaklaşık olarak içerdiği \% 7.5-15 ham protein ve $\% 75$ oranında da hazm olunabilir besin maddeleri ile birlikte çok iyi bir besin kaynağıdır (Akkaya, 1984). Ülkemizde hayvanların besin maddeleri kaynaklarından, ham protein ihtiyaçlarının \% 9.45'i, nişasta değerinin ise \% 12.20 'si arpadan karşılanmaktadır (Tosun ve Altın, 1986). Bugün ülkemizde tarıma elverişli toprakların hepsi üretimde kullanılmakta ve böylece ekim alanlarını arttırma imkanı bulunmamaktadır. Bu nedenle, artan nüfusun

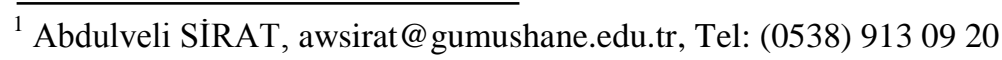


gereksinmelerini karşılamak amacıyla birim alandan elde edilen ürün miktarının artırılması gerekmektedir. Dolayısıyla, arpa verimine etkili olabilecek faktörlerin çeşitli toprak ve iklim koşullarında denenmesi, bunun yanında birim alandan elde edilen ürün miktarını arttırmak için yüksek nitelikli tohumluk kullanımı, uygun gübreleme, zirai mücadele tekniği ve en önemlisi iyi bir toprak işleme ve tohum yatağı hazırlama gibi tarım tekniklerinin uygulanması gerekmektedir. Arpada verimin yüksek olması çevre şartlarına, çeşide ve kültürel uygulamalara bağlıdır.

Tahıllarda verim tane ürünüdür ve tane verimini birim alandaki başak sayısı, başaktaki tane sayısı ve tane ağırlığ belirlemektedir (Kayaçetin ve Kırtok, 2010). Arpada birim alanda optimum bitki sayıs sağlandığı sürece daha yüksek tane verimi almak olasıdır.

$\mathrm{Bu}$ çalışma ile hayvan beslenmesi olmak üzere, malt ve bira endüstrisinde, az da olsa insan beslenmesinde önemli bir yeri olan ve ülkemizin hemen her yöresinde başarı ile yetiştirilen bir tahıl cinsi olan arpa ile ilgili olarak, Samsun koşullarında üretim verileri ve üretim düzeyleri tartışılmıştır.

\section{Türkiye'de Arpa Tarımının Önemi}

Arpa, dünyada 49.3 milyon hektar ekim alan1, 132.3 milyon ton üretimi ile buğday, çeltik ve misırdan sonra dördüncü önemli tahıl cinsi olup ortalama verimi $268.4 \mathrm{~kg} / \mathrm{da}$ 'dır (Anonim, 2012a). Ülkemizde arpa ekim alanı 2.7 milyon hektar olup, üretim 7.1 milyon ton ve verimi ise $258 \mathrm{~kg} / \mathrm{da}$ 'dır (Anonim, 2012b). Samsun ilinde ise toplam arpa ekim alanı 7.735 ha, üretim 25.253 ton ve verim ise $326.5 \mathrm{~kg} / \mathrm{da}$ 'dır (Anonim, 2012c).

Arpa, Türkiye'nin yaklaş1k tüm bölgelerinde yetiştirilmekte, özellikle Orta Karadeniz (Samsun, Amasya, Tokat, Çorum) Bölgesi arpa yetiştiriciliği konusunda önemli bir yere sahiptir. Türkiye'nin kendine yeterli tarımsal ürünlerinden biri olan arpa, kaba ve karma yem açığının önemli bir bölümünün kapatılmasına yardımcı olmaktadır. Üretimin tamamına yakını iç piyasada tüketilmektedir. Yapılan ıslah çalışmaları ile yüksek verimli ve kaliteli çeşitlerin geliştirilmesiyle hem iç tüketim isteklerine cevap verecek hem de ihraç etme imkanları doğacaktır (Kılınç vd., 1992).

Ülkemizde, 2000-2012 yılları arasında istatistik verilerine göre arpa ekim alanı, üretim ve verimi y1llar itibariyle dalgalanma göstermektedir (Tablo 1). Tablo 1'de görüldüğü gibi arpa ekim alanı 3.650-2.869 bin hektar, üretim miktarı 8.000-7.100 bin ton ve dekara verimi ise $220.4-258.0 \mathrm{~kg}$ arasında değişmiştir (Tablo 1). Y1llara göre arpa üretimindeki dalgalanma, bu bitkinin tarımının büyük ölçüde yağışa bağlı marjinal alanlarda yapıldığını ve su potansiyelinden yeterince yararlanılamadığını göstermektedir (Anonim, 2007). Geniş alanlarda üretilen ve büyük halk kitlelerinin önemli bir gelir kaynağı olan arpanın üretim ve veriminin artırılması için, üretim bölgelerinin ekolojik koşullarına uyum sağlayacak çeşitlerin ve uygun yetiştirme tekniklerinin bulunmasının önemi büyüktür (Turgut vd., 1997).

Arpa tarımı Türkiye'de büyük ölçüde kuru koşullarda yapıldığı için verimi düşüktür. Türkiye'nin arpa verimi bazı yıllar dünya arpa veriminin altındadır. Bunun nedeni ise, iklime bağlı olarak bazı yıllar belirgin artışlar, bazı yıllarda ise belirgin azalışlar meydana gelmektedir. Arpa veriminin yükseltilmesi için kaliteli tohumluk kullanımı önemli bir faktördür. Tohumluk dağıtımının istenilen seviyeye ulaşması için, üreticilerin sertifikalı tohumluk kullanımı açısından teşvik edilmesi gerekmektedir (Anonim, 2007).

Türkiye'de tüketilen arpa miktarı her geçen yıl artış göstermektedir. Hayvancılığın gelişmesiyle artan yemlik arpa ihtiyacı yanında, malt sanayinde kurulu kapasite artış1 maltlık arpaya olan talebi de yükselmiştir. Ülkemizin biralık arpa ihtiyacı yıllık 250.000 ton arasında olup, bu miktar toplam üretimin $\%$ 3.5'idir. Ancak kalitenin uygun olmamas1 nedeniyle, bu miktarın temininde, bazı yıllarda güçlükler yaşanmakta ve ortaya çıkan hammadde açığı ithalat yolu ile karşılanmaktadır. 
Tablo 1. Türkiye'de 2000-2012 yıllar arası arpa ekim alanı, üretimi, verimi, ihracatı ve ithalatı

\begin{tabular}{|c|c|c|c|c|c|}
\hline Y1llar & $\begin{array}{c}\text { Ekim Alan1 } \\
(000 \mathrm{ha})\end{array}$ & $\begin{array}{c}\text { Üretim } \\
(000 \text { ton })\end{array}$ & $\begin{array}{c}\text { Verim } \\
\text { (kg/da) }\end{array}$ & $\begin{array}{c}\text { İthalat } \\
\text { (ton) }\end{array}$ & $\begin{array}{c}\text { İhracat } \\
\text { (ton) }\end{array}$ \\
\hline 2000 & 3.629 & 8.000 & 220.4 & 40.216 & 186.205 \\
\hline 2001 & 3.640 & 7.500 & 206.0 & 38.967 & 158.216 \\
\hline 2002 & 3.600 & 8.300 & 231.0 & 16.756 & 595.825 \\
\hline 2003 & 3.400 & 8.100 & 238.0 & 89.428 & 395.988 \\
\hline 2004 & 3.600 & 9.000 & 250.0 & 240.340 & 000.150 \\
\hline 2005 & 3.650 & 9.500 & 260.0 & 52.182 & 289.394 \\
\hline 2006 & 3.650 & 9.551 & 262.0 & 65.963 & 410.498 \\
\hline 2007 & 3.428 & 7.307 & 213.0 & 52.180 & 215.780 \\
\hline 2008 & 2.950 & 5.923 & 201.0 & 253.014 & 0 \\
\hline 2009 & 3.010 & 7.300 & 243.0 & 91.649 & 301.304 \\
\hline 2010 & 3.040 & 7.250 & 238.0 & 57.076 & 500.791 \\
\hline 2011 & 2.869 & 7.600 & 265.0 & 36.132 & 3.221 \\
\hline 2012 & 2.749 & 7.100 & 258.0 & \multicolumn{3}{|l}{} \\
\hline \multicolumn{7}{|l|}{ Kaynak: Anonim, $2012 \mathrm{~b}$} & & \multicolumn{5}{|l}{ Kaynak: Anonim, 2011a } \\
\hline
\end{tabular}

Türkiye'nin malt iç tüketimi yanında ihracatının da günden güne artması, dünya standartlarında kaliteli biralık arpa çeşitlerinin geliştirilmesi zorunluluğunu ortaya çıkarmıştır (Öztürk vd., 1997; Sirat, 2004).

Türkiye'nin arpa ithalatı oldukça az olmakla birlikte daha çok kaliteli biralık arpa ithalatı yapılmaktadir. 2000-2012 yilları arasinda dalgalı bir seyir izleyen Türkiye arpa ithalatı, 2004 ve 2008 yıllarında en yüksek değerine ulaşmıştır. Arpa ithalatında uygulanan cari gümrük vergisi oran1 \%100'dür (Tablo 1).

2000-2012 yılları arasında Türkiye'nin arpa ihracatı incelendiğinde, ihracatın en fazla 2002 ve 2010 yıllarında gerçekleştiği görülmektedir. Arpa ayrıca malt ve bira olarak da ihraç edilmektedir (Tablo 1).

\section{Samsun İli'nin Biyofiziksel Özellikleri}

\section{1. İlin Konumu}

Karadeniz sahil şeridinin orta bölümünde Yeşilırmak ve Kızılırmak nehirlerinin Karadeniz'e döküldükleri deltalar arasında yer alan Samsun ili $9.579 \mathrm{~km}^{2}$ 'lik bir yüz ölçümüne sahiptir. Coğrafi konum olarak $40^{\circ} 50^{\prime}$ ve $41^{\circ} 51^{\prime}$ kuzey enlemleri, $37^{\circ} 08^{\prime}$ ve $34^{\circ} 25^{\prime}$ doğu boylamları arasındadır. Samsun İli Karadeniz Bölgesinin orta kesiminde yer alır. Kuzeyinde Karadeniz'in yer aldığ 1 ilin komşuları; doğusunda Ordu (Ünye ve Akkuş İlçeleri), batısında Sinop (Durağan ve Gerze İlçeleri), güneyinde ise Tokat (Erbaa ilçesi), Amasya (Merkez ve Taşova, Suluova, Merzifon, Gümüşhacıköy İlçeleri) ve Çorum (Osmancık İlçesi) yer alır (Anonim, 2011b).

\subsubsection{Agroekolojik Alt Bölgeler}

Agro-ekolojik bölgelendirme, arazinin çevresel özellikleri, potansiyel verim ve arazi uygunluğu benzer olan özelliklere sahip alt alanlara bölünmesini ifade eder.

Bir agro-ekolojik bölge iklim, arazi formu, toprak yapısı ve/veya arazi örtüsüne göre belirlenir. Bu kapsamda Samsun İli 3 agroekolojik bölgeye ayrilarak incelenmiştir. Alt bölgeler içerisindeki İlçeler (17 adet) Tablo 2 ve Şekil 1'de görülmektedir (Anonim, 2011b). 
Tablo 2. Samsun ilinin agro-ekolojik alt bölgeleri

\begin{tabular}{|l|l|l|}
\hline \multicolumn{1}{|c|}{ I. ALT BÖLGE } & \multicolumn{1}{c|}{ II. ALT BÖLGE } & III. ALT BÖLGE \\
\hline Atakum (Merkez ilçe) & Asarcık & Ayvacık \\
\hline Canik(Merkez İlçe) & Havza & Salıpazarı \\
\hline İlkadım (Merkez İlçe) & Kavak & \\
\hline Tekkeköy (Merkez İlçe) & Ladik & \\
\hline Alaçam & Vezirköprü & \\
\hline Bafra & & \\
\hline Çarşamba & & \\
\hline 19 Mayıs & & \\
\hline Terme & & \\
\hline Yakakent & & \\
\hline
\end{tabular}

Kaynak: Anonim, 2011b.

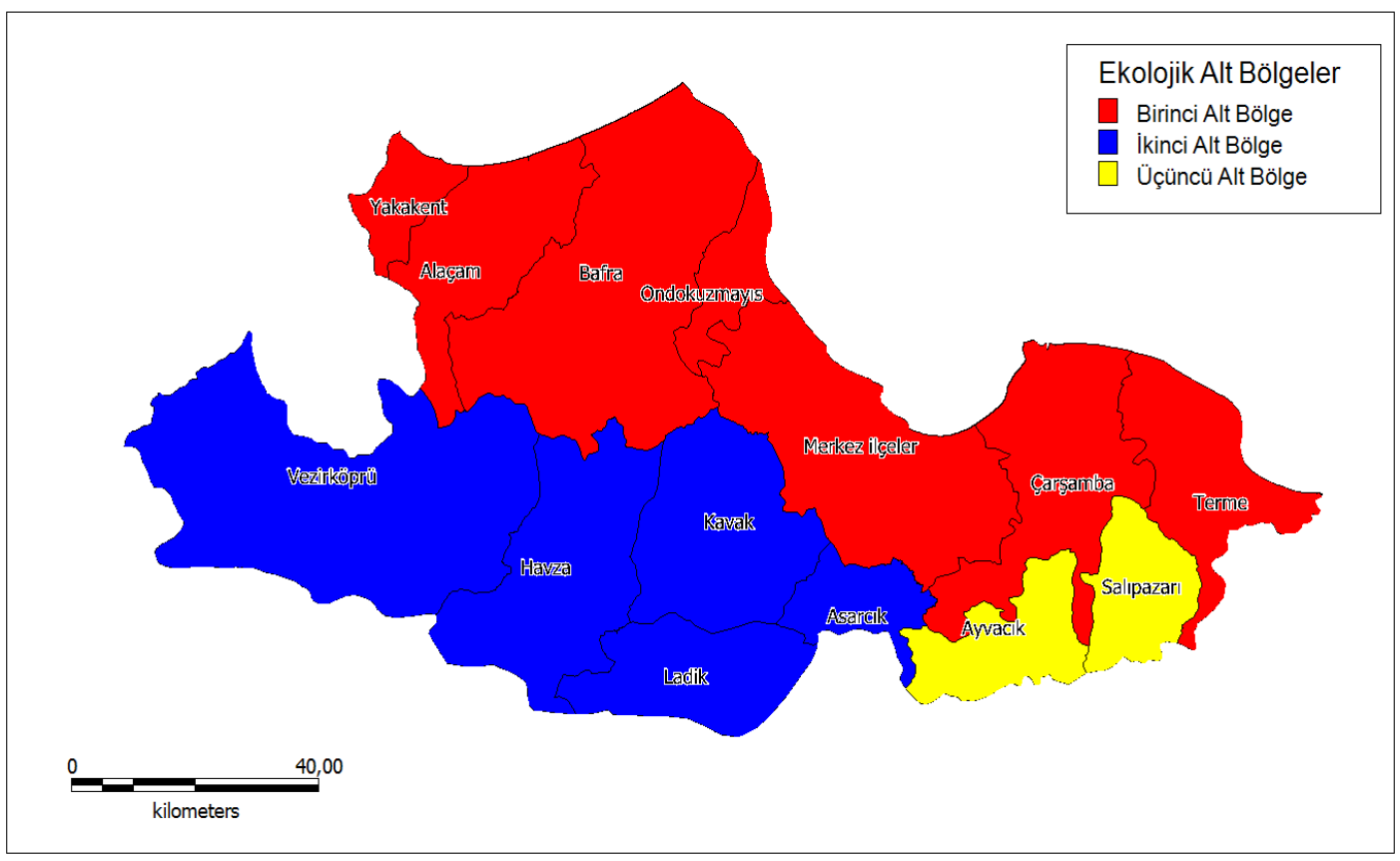

Şekil 1. Samsun ilinin agro-ekolojik alt bölgeleri (Anonim, 2011b)

\section{2. İklim Özellikleri}

Samsun genellikle 1lıman bir iklime sahiptir. Ancak sahil şeridinde ve iç kesimlerde iklim iki ayrı özellik gösterir. Sahil şeridinde (Merkez ilçe, Terme, Çarşamba, Bafra, Alaçam, Yakakent, 19 Mayıs) Karadeniz ikliminin etkileri görülür. Bunun için sahil şeridinde yazlar sıcak, kışlar ılık ve yağışlı geçer. İç kesimler (Vezirköprü, Havza, Ladik, Kavak, Asarcık, Salıpazarı ve Ayvacık) yüksekliği 2000 metreyi bulan Akdağ ve 1500 metreyi bulan Canik Dağlarının etkisi altında kalır. Burada dağların etkisinden kışlar soğuk, yağmur ve kar yağgşlı, yazlar ise serin geçer (Anonim, 2011b).

Samsun İli sıcaklık ve yağışlar açısından Doğu ve Batı Karadeniz iklimine benzemektedir. Yağışı Doğu Karadeniz Bölgesine göre az, sıcaklık ortalaması açısından ise yüksektir. İlin iç kesimleri ise deniz etkisinden uzak olduğu için daha soğuktur. Kıyı kesiminde ise kışlar 1 lık, ilkbahar sisli ve serin, yaz mevsimi ise kuraktır. 1960-2012 yılları ortalamasına göre, 
Samsun'da y1llı ortalama sicaklık 14.5 ${ }^{\circ} \mathrm{C}$ 'dir. Yillık ortalamalarına göre en sicak geçen aylar Temmuz $\left(23.3{ }^{\circ} \mathrm{C}\right)$ ve Ağustos $\left(23.4{ }^{\circ} \mathrm{C}\right)$, en soğuk geçen aylar ise Ocak $(7.0$ $\left.{ }^{\circ} \mathrm{C}\right)$ ve Şubat $\left(6.9{ }^{\circ} \mathrm{C}\right)$ aylarıdır. En yüksek sıcaklık ortalaması yıllık $18.3{ }^{\circ} \mathrm{C}$, en düşük sıcaklık ortalaması ise $11.0{ }^{\circ} \mathrm{C}^{\prime}$ dir. En düşük sıcaklık ortalaması Ocak $\left(4.1^{\circ} \mathrm{C}\right)$, Şubat $(3.8$ $\left.{ }^{\circ} \mathrm{C}\right)$ ve Mart $\left(4.8^{\circ} \mathrm{C}\right)$ görülmektedir. En yüksek sicaklık ise ortalaması Temmuz $\left(26,5{ }^{\circ} \mathrm{C}\right)$ ve Ağustos $\left(27.0^{\circ} \mathrm{C}\right.$ ) aylarına aittir (Tablo 3).

Tablo 3. Samsun iline ait bazı meteorolojik verileri

\begin{tabular}{|c|c|c|c|c|c|c|c|c|c|c|c|c|c|}
\hline Aylar & Ocak & Şubat & Mart & Nisan & Mayıs & Haziran & Temmuz & Ağustos & Eylül & Ekim & Kasım & Aralık & Y1llik \\
\hline \multicolumn{14}{|c|}{ Sicaklık $\left({ }^{0} \mathrm{C}\right)$} \\
\hline $\begin{array}{c}\text { Ortalama } \\
\text { Sicaklik }\left({ }^{\circ} \mathrm{C}\right)\end{array}$ & 7.0 & 6.9 & 8.0 & 11.3 & 15.6 & 20.3 & 23.3 & 23.4 & 20.0 & 16.1 & 12.4 & 9.3 & 14.5 \\
\hline $\begin{array}{c}\text { En Düşük } \\
\text { Sicaklık }\left({ }^{\circ} \mathrm{C}\right) \\
\text { Ortalaması }\end{array}$ & 4.1 & 3.8 & 4.8 & 7.9 & 12.0 & 16.2 & 19.2 & 19.6 & 16.5 & 12.9 & 9.1 & 6.4 & 11.0 \\
\hline $\begin{array}{c}\text { En Yüksek } \\
\text { Sicaklık }\left({ }^{\circ} \mathrm{C}\right) \\
\text { Ortalaması }\end{array}$ & 10.8 & 11.0 & 12.1 & 15.3 & 19.0 & 23.7 & 26.5 & 27.0 & 23.9 & 20.2 & 16.7 & 13.1 & 18.3 \\
\hline $\begin{array}{c}\text { En Yüksek } \\
\text { Sicaklık }\left({ }^{\circ} \mathrm{C}\right)\end{array}$ & 24.2 & 26.2 & 32.3 & 37.0 & 36.4 & 37.4 & 37.5 & 35.2 & 38.3 & 38.4 & 30.0 & 28.9 & 33.5 \\
\hline \multicolumn{14}{|c|}{ Nispi Nem (\%) } \\
\hline $\begin{array}{l}\text { Nispi Nem } \\
\text { Ortalamas1 } \\
\end{array}$ & 67.1 & 69.5 & 75.1 & 79.1 & 80.2 & 76.0 & 73.6 & 73.6 & 75.2 & 75.8 & 69.8 & 66.4 & 73.5 \\
\hline $\begin{array}{l}\text { Nispi Nem } \\
\text { (En Yüksek) }\end{array}$ & 98 & 97 & 100 & 100 & 100 & 98 & 96 & 97 & 97 & 98 & 100 & 98 & 100 \\
\hline $\begin{array}{l}\text { Nispi Nem } \\
\text { (En Düşük) }\end{array}$ & 6.0 & 2.0 & 5.0 & 14.0 & 20.0 & 27.0 & 20.0 & 36.0 & 18.0 & 5.0 & 10.0 & 5.0 & 2.0 \\
\hline \multicolumn{14}{|c|}{ Yağış (mm) } \\
\hline $\begin{array}{l}\text { Aylık Yağı̧s } \\
\text { Toplamı }\end{array}$ & 64.4 & 53.9 & 60.3 & 58.9 & 49.8 & 47.3 & 32.8 & 37.9 & 51.9 & 84.0 & 85.2 & 79.7 & 706.1 \\
\hline $\begin{array}{c}\text { En Fazla } \\
\text { Yağıș Miktarı }\end{array}$ & 45.7 & 39.9 & 31.1 & 45.6 & 56.2 & 77.5 & 54.6 & 113.2 & 58.4 & 63.1 & 66.5 & 42.0 & 693.8 \\
\hline & & & & & & & & & & & & & \\
\hline & & & & & & & & & & & & & \\
\hline
\end{tabular}

Not: 1960-2012 yılı arasında gözlenen değerler üzerinden alınan uzun yıllar ortalamasıdır.

Kaynak: Anonim, 2011c.

Samsun'da nispi nem oranı ülke ortalamasının hayli üzerindedir (\% 73.5). İlkbahar mevsimi en yüksek nem oranı ortalamasina sahiptir $(\%$ 78.1). En düşük nem oranı ortalaması kış mevsiminde \% 67.7 olmaktadır. Sonbahar ve yaz aylarında nispi nem oranları ortalaması ise sirasiyla 73.6 ve 74.4 'tür. Samsun'da yaz aylarında nispi nemin yüksek olması nedeniyle hava sicaklığ yüksek hissedilir (Tablo 3).

Aylık ortalama yağış miktarı ülkenin ortalamasının üzerindedir $(706.1 \mathrm{~mm})$. Buna karşılık ildeki yağış oranı Batı Karadeniz Bölgesi illerine göre değişiktir. 1960-2012 yılları ortalamasına göre ilde yağış en çok Ekim $(63,1 \mathrm{~mm}$.) ve $\operatorname{Kasim}(66,5 \mathrm{~mm}$.) aylarında olmaktadır (Tablo 3). İlin doğusundaki yağış miktarı batısına göre daha fazladır. Yıllık ortalama yağışlı gün sayısı ise 140'dir.

\section{Samsun İl'i Arpa Üretim Potansiyeli}

Samsun ilinin yüzölçümü yaklaşık 960 bin hektar olup, bunun \% 47,5'i tarım arazisi, \% 37,4 'ü orman ve fundalık arazi, \% 4,7 çayırmera arazisi ve \% 10, 4'ü de tarım dışı arazidir. Samsun ilinde tarım arazilerinde ekilen ürünlerin dağılımına bakıldığında yaklaşık 455 bin hektar tarım arazisinin \% 47,8'inde tahillar, \% 19,5'inde meyvecilik, \% 8,3'ünde endüstri bitkileri, \% 4,5'inde yemeklik baklagiller, \% 8,4'ünde sebze, $\%$ 0,6 'sinda yumrulu bitkiler ekilmekte olup, \% 2,7'si ise nadasa birakilmaktadır. Bu veriler ışı̆̆ında Samsun ilinin tarım arazisinin yaklaşık \% 70'inde (300 bin hektar) tarla bitkileri yetiştiriciliği yapılmaktadır (Sezer vd., 2011).

Samsun ilinde tahıllar tarla bitkileri içerisinde en çok yer tutan ürün grubu olması açısından 
büyük öneme sahiptir. Tahıl üretimi içinde özellikle arpa, buğday, misır ve çeltikten sonra önemli bir potansiyele sahiptir (Şekil 2). Yörenin doğal yapısı itibariyle hayvancılığın özel bir önem taşıması nedeniyle arpanın hayvan beslenmesinde kesif yem olarak değerlendirildiği görülmektedir.

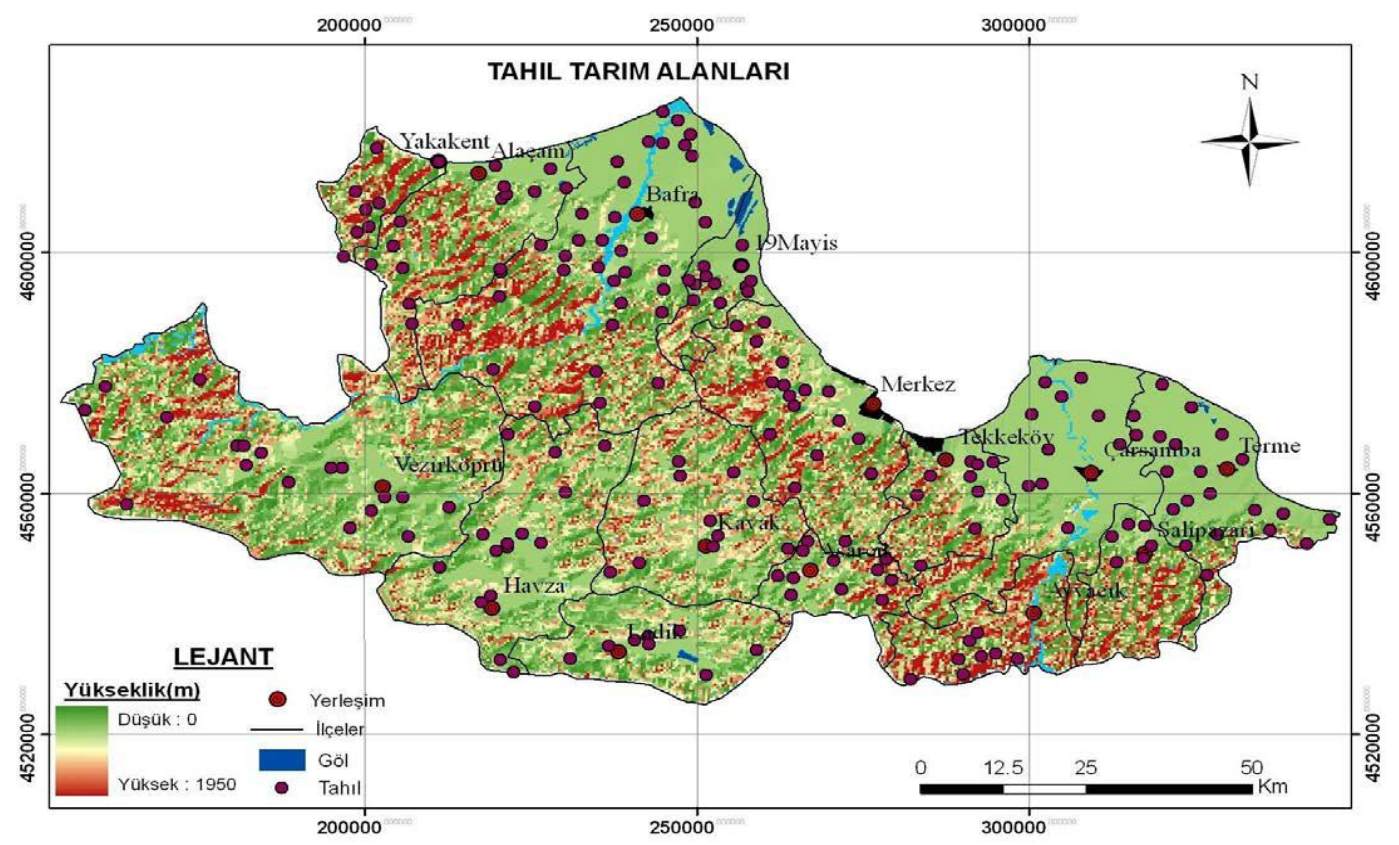

Şekil 2. Samsun ili tahıl tarım alanları haritası (Anonim, 2011b)

Tablo 4. Samsun ili 2000-2012 yıllar arası arpa üretim potansiyeli

\begin{tabular}{|c|c|c|c|}
\hline Y1llar & Ekim Alan1 (ha) & Üretim (ton) & Verim (kg/da) \\
\hline 2000 & 16135 & 46864 & 290.4 \\
\hline 2001 & 15372 & 45882 & 298.5 \\
\hline 2002 & 15692 & 37567 & 239.4 \\
\hline 2003 & 11790 & 31337 & 265.8 \\
\hline 2004 & 13907 & 36446 & 262.1 \\
\hline 2005 & 14234 & 37361 & 262.5 \\
\hline 2006 & 13328 & 34626 & 259.8 \\
\hline 2007 & 8673 & 25819 & 297.7 \\
\hline 2008 & 7986 & 26783 & 335.4 \\
\hline 2009 & 8076 & 21249 & 263.1 \\
\hline 2010 & 8418 & 20073 & 238.5 \\
\hline 2011 & 7735 & 20074 & 259.5 \\
\hline 2012 & 7821 & 18255 & 233.4 \\
\hline
\end{tabular}

Kaynak: Anonim, 2012b.

Samsun İli 2000-2012 yıllar aras1 arpa üretim potansiyeli Tablo 4'de verilmiştir. Tablo incelediğinde en fazla arpa ekim alanı 16.135 hektar ile 2000 yilında, en yüksek üretim miktarı ve verimi ise sirasiyla 46.864 ton ve $290.4 \mathrm{~kg} / \mathrm{da}$ ile 2000 y1lında gerçekleşmiştir. En düşük üretim ve verim ise 2012 yılında elde edilmiştir (Tablo 4). Onüç yılın istatistik verilerine bakıldığında ekim alanı, üretim ve verim miktarlarında bir dalgalama söz konusu olmuştur. Uzun yıllar aylık yağış ortalamalarına göre, yağışın çoğu kış ve sonbahar aylarında düşerken, yaz ve ilkbahar aylarında daha az yağış düşmektedir. 
Dolaysıyla, görülen bu farklılıklar üretimde yanlış seçilmiş arpa çeşitlerinden, tarımda yanlış uygulanan yöntemlerden ve yağışın aylara dağılımındaki düzensizlikten kaynaklanmış olabilir (Tablo 3).

Türkiye İstatistik Kurumu (TÜİK) ve Samsun Gıda, Tarım ve Hayvancılık İl Müdürlüğü istatistik verilerine göre arpa 2012 yllında Samsun İlinin ekim alanı 78.210 da, üretimi 18.255 ton ve dekara verimi ise $233.4 \mathrm{~kg}$ olmuştur (Tablo 4 ve 5). Samsun İlinin 17 İlçesinde (Atakum, Canik, İlkadım ve Tekkeköy (Merkez İlçeler), Alaçam, Asarcık, Ayvacık, Bafra, Çarşamba, Havza, Kavak, Ladik, 19 Mayıs, Salıpazarı, Terme,
Vezirköprü ve Yakakent) arpa tarımı yapılmaktadır (Tablo 5). Ancak Çarşamba ve Terme ilçelerin arpa üretimi düşük olduğu için, istatistiksel olarak yansıtılmamıştır (Anonim, 2011b).

Samsun İli agroekolojik alt bölgeleri arasında arpa üretim potansiyelini karşılaştıracak olursak, arpa üretiminde ilk sirayı 49.000 dekar ekim alanı ve il genel üretimindeki yaklaşık \% 65'lik üretim payı ile II. alt bölge almaktadır. I. alt bölgenin üretim payı \% 33.9 olup 26.825 da ekim alanı ile ikinci sırada yer almaktadır. III. alt bölge ise \% 1.1 gibi çok düşük bir rakamla arpa üretilmektedir (Tablo 5).

Tablo 5. Samsun ili 2012 yılı arpa üretim potansiyeli

\begin{tabular}{|c|c|c|c|c|c|c|}
\hline \multirow{2}{*}{\multicolumn{2}{|c|}{ SAMSUN }} & \multicolumn{2}{|c|}{ Ekim Alanı } & \multicolumn{2}{|c|}{ Üretim } & \multirow{2}{*}{$\begin{array}{c}\text { Verim } \\
\text { (kg/da) }\end{array}$} \\
\hline & & ha & $\%$ & ton & $\%$ & \\
\hline \multirow{11}{*}{ 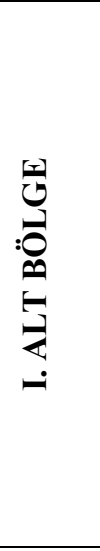 } & Atakum & 2.935 & 3.75 & 719 & 3.94 & 245.0 \\
\hline & Canik & 4.000 & 5.11 & 680 & 3.72 & 170.0 \\
\hline & İlkadım & 800 & 1.02 & 196 & 1.07 & 245.0 \\
\hline & Tekkeköy & 150 & 0.19 & 30 & 0.16 & 200.0 \\
\hline & Alaçam & 12.500 & 15.98 & 3.063 & 16.78 & 245.0 \\
\hline & Bafra & 5.000 & 6.39 & 1.370 & 7.50 & 274.0 \\
\hline & Çarşamba & 0 & 0 & 0 & 0 & 0 \\
\hline & 19 Mayıs & 1.000 & 1.28 & 245 & 1.34 & 245 \\
\hline & Terme & 0 & 0 & 0 & 0 & 0 \\
\hline & Yakakent & 1.700 & 2.17 & 306 & 1.68 & 180.0 \\
\hline & Toplam & 28.085 & 35.90 & 6.609 & 36.20 & \\
\hline \multirow{6}{*}{ 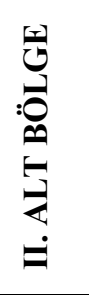 } & Asarcık & 4.200 & 5.37 & 714 & 3.91 & 170.0 \\
\hline & Havza & 16.500 & 21.10 & 4.043 & 22.15 & 245.0 \\
\hline & Kavak & 9.000 & 11.51 & 1.800 & 9.86 & 200.0 \\
\hline & Ladik & 5.900 & 7.54 & 1.465 & 8.03 & 248.0 \\
\hline & Vezirköprü & 13.000 & 16.62 & 3.364 & 18.43 & 259.0 \\
\hline & Toplam & 48.600 & 62.14 & 11.386 & 62.37 & \\
\hline \multirow{4}{*}{ 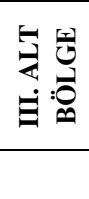 } & Ayvacık & 1.500 & 1.92 & 255 & 1.40 & 170.0 \\
\hline & Salıpazarı & 25 & 0.03 & 5 & 0.02 & 200.0 \\
\hline & Toplam & 1.525 & 1.95 & 260 & 1.42 & \\
\hline & Samsun & 78.210 & & 18.255 & & 233.4 \\
\hline
\end{tabular}

Kaynak: Anonim, 2012c.

\section{Türkiye'de Arpa Üretimindeki Sorunlar, Çözüm ve Öneriler}

\subsection{Arpa üretimindeki sorunlar}

- Parçalı arazi yapısı ve arazi toplulaştırmasına karşı tavırlar,
- Girdi fiyatlarının yüksekliği ve yetersiz ve bilinçsiz girdi kullanımı,

- Amacina uygun arazi kullanılmamasi,

- Alternatif ürün yetiştirme konusunda çiftçilerin çekingen davranması,

- Hastalık ve zararlılarla mücadele yöntemlerinin iyi bilinmemesi ve eski 
tarz yöntemlerle mücadele edilmesi, gereksiz ve yanlış ilaç kullanımının yaygın olmas1 ve bu sebeple ürünlerde kalıntının çok olması. Özellikle yabancı ot ilaçlarının kart dikenlere ve ilaçlanma zamanı geçmiş yabancı otlara karşı aşırı dozda kullanılması,

- Yeni çeşitlerin üreticiye tanıtımı ve ulaştırılmasındaki yetersizlik,

- Tarım alet ve makinelerinin optimum düzeyde kullanılamaması,

- Bazı ilçelerde taban suyu seviyesinin yüksek olması (göl ve deniz kıyısındaki ilçelerde) ve drenaj kanallarının eksikliği,

- İlkel yöntemlerle tarım yapılması, makineleşme eksikliği ve ürün kalitesinin düşük seviyede olması,

- Yeteri derecede toprak tahlillerinin yapılmaması ve gübre kullanımında toprak özelliklerinin dikkate alınmaması,

- Çiftçi eğitiminin eksik olması, planlı üretim eksikliği,

- Toprak işlemenin yanlış yapılması, arka arkaya aynı ürünlerin ekilmesi,

- Türkiye genelinde girdi fiyatları genellikle yıllık enflasyon düzeyinde veya üstünde artmakta iken ürün fiyatları gerçekleşen enflasyonun altında kalmaktadır. Düşük gelir grubu içinde kalan üretici yeterli girdi temininde güçlüklerle karşı karşıyadır,

- Sertifikalı tohumluk kullanımı yönünden tahıllar miktar olarak bir hayli yüksek değerler gösteriyorsa da, toplam ekim alanı yönünden kıyaslandığında yetersiz olduğu görülmektedir. Serin iklim tahıllarında verim potansiyeli yüksek, hastalık ve zararlılara dirençli, kaliteli ıslah çeşitlerinin kullanımının düşük olduğu bilinmektedir,

- Türkiye'de arpa tarımı yapılan alanların büyük bir kısmını kurak ve yarı kurak alanlar oluşturduğundan bu alanlarda gübre kullanımı yağış miktarı ve dağılışına bağglıdır. Sulama yapilabilen alanlarda ise gübre kullanımı daha yoğundur,

- Kışlık tahıllarda ilaç kullanımı iki safhada yoğunlaşmaktadır. Genellikle sürme ve rastık hastalıkları ile mücadelede ve yine zabrus ve diğer zararliların erken dönemde yapacakları zararı önlemek amacıyla tohum ilaçlaması yapılmaktadır. Daha sonraki dönemde ise süne ve kımıl zararına karşı yapılan ilaçlamadır.

- Makine ve ekipman gibi mekanik teknoloji unsurları, bitkisel üretimde tohum, gübre, ilaç ve sulama suyu gibi teknolojik öğelerin verim ve üretim üzerine etkilerini tamamlayan ve artıran bir özelliğe sahiptir. Hatta bazı yeni ve ileri üretim teknolojilerinin uygulanması tüm makine ve ekipman değişimini gerektirmektedir.

\section{2. Çözüm ve Öneriler}

Arpa üretiminde, üstün verim ve kalite özelliklerine sahip, hastalık ve zararlılara dayanıklı ve çevresel streslere dirençli yeni çeşitlere ihtiyaç devam etmektedir. Bu amaçla ıslah programlarının teşvik edilmesi ve desteklenmesi gerekmektedir. Ayrica, arpa tarımını etkileyen en önemli faktörler; toprak hazırlığg1, ekim, uygulanan gübre, zirai mücadele, hasat zamanı gibi faktörlerdir. $\mathrm{Bu}$ uygulamalar teknik olarak iklim, sulamasızsulamalı şartlar, toprak doku ve yapısına göre farkl1lık gösterir.

Sertifikalı ve kaliteli tohumluk kullanım oranı arttırılmalı ve teşvik edilmelidir.

Arpa buğdaya nazaran daha az bakım yapılan bir bitkidir. Bununla beraber, arpanın buğdaya nazaran daha verimli toprak isteği vardır. Değişik yörelere uygun üretim yöntemleri bilinmesine karşın; çiftçiler, daha çok geleneksel yöntemleri uygulamaktadır.

Üretim teknolojisinde özellikle Güney Doğu Anadolu Projesi ve ayrıca küçük çiftçi sulamalarına dayalı olarak sulama alanlarının arttığ1; bu alanların bir kısmında tahıl tarımı yapılmasinın toprak yapisinin korunması açısından zorunlu olduğu göz önüne alınarak arpanın ekim nöbetine alınabileceği düşünülmektedir. $\mathrm{Bu}$ alanlarda uygun arpa yetiştirme yöntemlerinin ortaya konması gerekmektedir. 
Kuru (sulamasız) tarım alanlarında azaltılmış toprak işleme yöntemlerinin geliştirilmesi bu alanlarda toprak erozyonunu azaltacak ve çevre korunmasına katkıda bulunacaktır.

Ülkemizde GAP'ın devreye girmesiyle bilinçsiz sulama sonucu ortaya çıkacak çoraklaşma problemlerinin çözümünde arpa bölgede uygulanabilecek ekim nöbetlerinde öncelikli olarak düşünülmesi gereken bir bitkidir.

Maltlık arpa toprakta fazla $\mathrm{N}$ artığı bırakan ön bitkiler ile ekim nöbetine girmemelidir. Baklagiller toprakta fazla $\mathrm{N}$ birakır. Buna bağlı olarak protein oranını yükseltir. Biralık arpada protein, kalite üzerine olumsuz etki yapar. Maltlık arpa tanesinde yüksek oranda protein istenmeyen bir özelliktir.

Maltlik arpalar uygun nemde hasat edilmelidir. İyice kurumadan hasat edilen arpa taneleri kolayca kızışıp bozulur. $\mathrm{Bu}$ da depolamada önemli bir sorun teşkil eder. Hasat için tanedeki nem oranı \% 13.5'in altında olması istenir. Arpada tane dökme olayı görülmez. Asıl sorun başak ve başak ekseni kırılmasıdır. Bu da hasat zamanının ayarlanması ve hasatta kullanılacak alet ve makinelerin seçimi ile giderilebilir.

\section{Sonuç}

Arpa dünyada ve ülkemizde hayvan beslemede yemlik olarak ve endüstride malt bira yapımında kullanılmak üzere başlıca iki amaçla yetiştirilmektedir. Arpanın malt kalitesini belirleyen en önemli faktörler çeşit ve üretimin yapıldığ 1 çevre koşullarıdır. Arpanın maltlık kalitesini belirlemek amacı ile birçok kalite analizi yapılmaktadır. Malt yapımında 2 ve 6 siralı arpalar kullanılmakta, ancak Türkiye'de 2 siralı arpalar tercih edilmektedir. 2 sıralı arpaların taneleri daha dolgun, kavuzları daha ince ve ekstrakt miktarı daha fazladır. Ülkemizde yetiştirilen çeşitlerimiz her yönden maltlık kalitesinin iyi olduğunu söylemek mümkün değildir. $\mathrm{Bu}$ durumda ülkemiz maltlık arpa konusunda ithalatçı, malt konusunda ise ihracatçı durumdadir.
Türkiye'nin arpaları, kaba ve karma yem açığının önemli bir bölümünü karşılamaktadır. Üretimin tamamına yakını iç piyasada tüketilmektedir. Arpa üretimi modern tarım teknikleri ile yapıldığında ürün kalitesi artacak ve ihraç etme olanakları ile ülkemize döviz getiren tarım ürünleri arasında yer alacaktır. Ayrıca, çorak arazilerin sslahında son derece önemli bir bitki olan arpanın GAP bölgesinde ekim nöbetine dahil edilmesi bilinçsiz sulama ile oluşacak çoraklaşmanın engellenmesinde önemli bir faktör olacaktır.

\section{Kaynaklar}

Akkaya, A., 1984. Kıraç Koşullarda Farklı Gübre Uygulamalarının Bazı Kışlık Arpa Çeşitlerinin Kışa Dayanıklılık, Verim, Verim Unsurlarına Etkileri. Atatürk Üniversitesi Ziraat Fakültesi Tarla Bitkileri Bölümü, Doktora Tezi, Erzurum.

Anonim, 2007. www.tarim.gov.tr (11.02.2014).

Anonim, 2011a. FAO Production Year Book. Food and Agriculture Organisation of United Nations, Roma. Alint1; http://faostat.fao.org/site/535/default.a spx\#ancor (11.02.2014).

Anonim, 2011b. Samsun ili Tarım Master Planı. Gida, Tarım ve Hayvancılık Bakanlığ 1 , Araştırma Geliştirme Daire Başkanlığı, Samsun İl Özel İdaresi. http://www.samsunozelidare.gov.tr/Ne wsDownload/OH9B2Samsun_ili_tari m_master_plani.pdf. (25.12.2013).

Anonim, 2011c. Devlet Meteoroloji İşleri Genel Müdürlüğü (DMİ). Ankara. http://www.mgm.gov.tr/veridegerlendi rme/il-ve-ilceleristatistik.aspx $? \mathrm{~m}=\mathrm{SAMSUN}$, (11.02.2014). 
Anonim, 2012a. FAO Production Year Book. Food and Agriculture Organisation of United Nations, Roma. Alınt1; http://faostat.fao.org/site/567/default.a spx\#ancor (http:// www.fao.org/organicag/)

(11.02.2014).

Anonim, 2012b. Türkiye İstatistik Kurumu (TÜİK). Alınt;; http://www.tuik.gov.tr/VeriBilgi.do?al

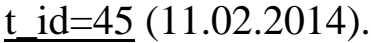

Anonim, 2012c. Samsun Gida, Tarim ve Hayvancilık İl Müdürlüğü İstatistik Verileri.

http://www.samsuntarim.gov.tr/html_d osyalar/istatistiklerle_samsun_tarimi.h $\underline{\operatorname{tm}}(21.12 .2013)$.

Kayaçetin, F. ve Kurtok, Y., 2010. Ankara Koşullarında Ekim Makineleri, Bitki Siklıkları ve Merdane Uygulamasinın Arpa (Hordeum vulgare L.)'da Tane Verimine ve Bazı Verim Özelliklerine Etkisi. Yüzüncü Y1l Üniversitesi, Tarım Bilimleri Dergisi, 20(2): 107122, Van.

Kilınç, M., Kırtok, Y. ve Yağbasanlar, T., 1992. Çukurova Koşullarına Uygun Arpa Çeşitlerinin Geliştirilmesi Üzerine Araştırmalar II. Arpa-Malt Semineri, 25-27 Mayıs 1992, s.205218 , Konya.

Öztürk, A., Çağlar, Ö. ve Akten, Ş., 1997. Erzurum Yöresinde Maltlık Olarak Yetiştirilebilecek Arpa Genotiplerinin Belirlenmesi. Ondokuz Mayıs Üniversitesi, Ziraat Fakültesi, Türkiye II. Tarla Bitkileri Kongresi, 22-25 Eylül, Samsun.

Sezer, İ., Kurt., O., Öner., F., Uysal., H., Akay., H. ve Demir, A., 2011. Samsun İlinde Tarım ve Çevre Açısından Uygulanabilecek Tarla Tarım Üretim Sistemlerinin İrdelenmesi. Samsun Sempozyumu 13-16 Ekim (sunulu bildiri), Samsun.
Sirat, A., 2004. Samsun Ekolojik Koşullarına Uygun Maltlik ve Yemlik Arpa (Hordeum vulgare L.) Çeşitlerinin Belirlenmesi Üzerine Araştırmalar. Ondokuz Mayıs Üniversitesi, Fen Bilimleri Enstitüsü, Tarla Bitkileri Ana Bilim Dalı (Basılmamış Yüksek Lisans Tezi), Samsun.

Tosun, F. ve Altın, M., 1986. Çayır Mera, Yayla Kültürü ve Bunlardan Faydalanma Yöntemleri. Ondokuz Mayıs Üniversitesi, Ziraat Fakültesi, Yayın No:1, Ders Kitapları Serisi No:1, Samsun.

Turgut, İ., Konak, C., Zeybek, A., Acartürk, E. ve Y1lmaz, R., 1997. Büyük Menderes Havzası Sulu Koşullarına Uyumlu Buğday Çeşitlerinin Belirlenmesi Üzerine Araştırmalar. Türkiye II. Tarla Bitkileri Kongresi, 22-25 Eylül 1997, s., 520-527, Samsun. 